\title{
ЗАСТОСУВАННЯ ІННОВАЦІЙНИХ ТЕХНОЛОГІЙ ЯК ЗАПОРУКА ПІДВИЩЕННЯ ЕФЕКТИВНОСТІ ТА ЯКОСТІ НАВЧАННЯ У ВИЩІЙ ШКОЛІ
}

\author{
С. І. Дубінін, А. В. Ваценко, В. О. Пілюгін, Н. А. Улановська-Циба, \\ Н. О. Передерій, О. Б. Рябушко, О. В. Овчаренко \\ Вищий державний навчальний заклад України \\ “Українська медична стоматологічна академія”, м. Полтава
}

\section{APPLICATION OF INNOVATIVE TECHNOLOGIES AS A GUARANTEE OF AN INCREASED EFFICIENCY AND QUALITY OF TEACHING IN HIGHER EDUCATION}

\author{
S. I. Dubinin, A. V. Vatsenko, V. O. Piliuhin, N. A. Ulanovska-Tsyba, N. O. Perederii, \\ O. B. Ryabushko, O. V. Ovcharenko \\ Ukrainian Medical Stomatological Academy, Poltava
}

\begin{abstract}
У статті, з метою інтеграції навчального процесу до Європейського простору, проаналізовані деякі сучасні застосування інтерактивних методів навчання, зокрема мультимедійних технологій та комп'ютерного тестування. В умовах інформатизації суспільства і бурхливого розвитку техніки перед викладачами постають нові завдання до організації науково-методичного підходу викладання фахових дисциплін. Сучасний підхід передбачає презентацію нового матеріалу при великому обсязі інформації за певний час, ефективну організацію навчального процесу та об'єктивного оцінювання його результатів.
\end{abstract}

This article aims to characterize an integration of the process of education to European area, some current problems of the interactive teaching methods have been analyzed including multimedia technologies and computer testing. In terms of the rapid development of the society teachers are facing the new challenges of the scientific and methodical approaches to professional disciplines. The modern approach involves a presentation of the new materials allowing for the large volume of educational information at a certain period of time and effective organization of the process of education and objective evaluation of the results.

Вступ. Рівень організації освітнього процесу у вищому навчальному закладі повинен відповідати світовим стандартам вищої школи, забезпечувати активне мотивоване здобуття студентами професійних знань та набуття якісної освіти. Вхід України до Болонського процесу забезпечив її інтеграцію до Європейського освітнього простору. Виходячи з цього, навчання студентів у сучасних умовах потребує вдосконалення та оновлення форм і методів, а також засобів навчання. Широке впровадження інформаційних технологій для підготовки майбутніх спеціалістів зумовлене зростанням кількості

(ㄷ) С. І. Дубінін, А. В. Ваценко, В. О. Пілюгін та ін. навчальної інформації, необхідністю ї̈ швидкого засвоєння, узагальнення та аналізу, систематизації всього комплексу теоретичних знань. Оновлений зміст освіти, адекватні методи та сучасні технології навчання зумовлюють формування компетентностей студентів. В свою чергу, інтеграцією медіа-освіти в систему роботи викладача $є$ використання сучасних методик та нових освітніх технологій $[2,4]$.

Загальним спрямуванням інновацій у вищій школі повинні стати: індивідуалізація навчальної діяльності студентів, активація їх навчання, підвищення рівня мотивації та відповідальності за якість засвоєння навчального матеріалу, необхідного для підготовки сучасного спеціаліста [1]. 
Інтерактивні методи навчання направлені на формування інформаційно-комунікаційних технологій, накопичення знань для застосування в майбутній практичній діяльності.

Основна частина. Основні інновації в процесі навчання студентів обумовлені застосуванням, переважно, інтерактивних методів. Впровадження інтерактивного навчання пов’язане з розвитком Інтернету і використанням інформаційних комп’ютерних технологій. Застосування нових комп’ютерних технологій прискорює навчальний процес і робить його цікавим і різноманітним.

Інтерактивне навчання передбачає взаємодію учасників навчального процесу в режимі діалогу або бесіди з викладачем чи з комп’ютером.

Застосування нових технологій дає змогу сформувати соціальні компетентності, а це і комунікативні навички, і презентаційні уміння. Що, в свою чергу, надає можливість у майбутньому ефективно взаємодіяти і приймати колективні рішення, експертні уміння і навички, уміння самостійно вирішувати ситуаційні задачі.

Сучасні студенти живуть у світі електронної культури. Для того щоб спілкуватися з ними однією мовою, викладачі опановують нові технології навчання, творчо працюють, здобуваючи нові компетенції. Вдосконалюють методичну роботу, розробляють нові методи навчання, застосовують їх, $€$ ініціаторами і реалізаторами ідей модернізації змісту освіти. Їх робота спрямована на створення умов для ефективної роботи зі студентами та отримання позитивного результату навчання. Сучасний викладач - це той, хто активно працює над саморозвитком, самовдосконаленням, збагаченням наукових, технологічних і методичних знань в умовах інформатизації суспільства.

За допомогою інформаційних технологій процес підготовки і передачі інформації студентам відбувається за допомогою комп'ютера з відповідним технічним та програмним забезпеченням. При цьому необхідно пам’ятати про те, що комп’ютер не може повністю замінити викладача, а лише доповнює його [3]

На нашу думку, однією з перспективних інновацій у навчальному процесі є мультимедійні технології. Їх використання дозволяє більш ефективніше демонструвати візуальний матеріал та створювати власні інноваційні розробки. Можливість використання колекції зображень, поєднання різних видів текстів, що супроводжуються анімацією, звуками, відео та іншими візуальними ефектами, створюють умови для активізації засвоєння інформації, роблять її більш наглядною і цікавою для опанування.

Студентам це дає можливість отримати більш глибше розуміння матеріалу, що вивчається, та економити час при його опрацюванні.

Складовими елементами системи забезпечення якості навчання при вивченні медико-біологічних дисциплін є діяльність викладачів, яка передбачає якісне інформаційне забезпечення студентів навчальними матеріалами, тестовими завданнями різних рівнів складності для самоконтролю знань, ефективне управління освітнім процесом, публічність інформації щодо освітніх програм та оцінювання здобувачів вищої освіти [5].

Використання мультимедійних технологій викладачами на лекціях і практичних заняттях надає можливість студентам зацікавитись новою інформацією, відразу включитися в роботу і легко опанувати наданий матеріал. Мультимедійна презентація один із ефективних методів організації навчання. Вона супроводжується коментарями викладача, передбачає можливість ставити запитання і робити пояснення.

Впровадження інноваційних технологій може бути ефективним і при оцінюванні знань студентів. Однією з форм оцінювання рівня знань студентів $€$ використання тестових завдань. Тестові завдання призначені для оцінювання досягнутого студентом рівня сформованості знань, умінь і навичок, професійних, світоглядних якостей і використовуються для встановлення відповідності рівня навчання вимогам стандартів вищої освіти.

В цьому напрямку комп’ютерний тестовий контроль знань допомагає вирішити проблеми якісного оцінювання знань студентів. Комп’ютерний тестовий контроль дає можливість одержати адекватну інформацію про якість навчання студентів завдяки наявності чіткого алгоритму дій і єдиного підходу до проведення контролю з об’єктивним оцінюванням результатів.

Комп’ютерне тестування дає можливість здійснювати швидкий і одночасний контроль знань у групах студентів з отриманням результатів тестування відразу після закінчення тесту, що має свої переваги. Під час проведення комп’ютерного контролю всі студенти перебувають у рівних умовах і тим самим досягається максимальна об’єктивність контролю, практично виключена можливість користування літературними джерелами (індивідуальні завдання для кожного студента та обмеження часу на відповідь) [6]. 
Для комп’ютерного тестування використовуються тести з бази даних Крок-1 та тести, які розроблені викладачами кафедри. Тестові завдання повинні бути: валідними (адекватними, обгрунтованими), мати наукову достовірність, репрезентативними (зміст тесту повний і достатній для прийняття рішення), об’єктивними, визначеними (загальнозрозумілими) та дискретними. Вони повинні бути практичними, простими у використанні. Відповідати джерелам інформації, запропонованим програмою відповідної дисципліни. Відповідей на тестові завдання повинно бути не менше п’яти. I неправильні відповіді повинні включати найбільш типові помилки.

На кафедрі медичної біології підготовлена та вдосконалюється комп’ютерна програма, яка дозволяє проводити тестування, як за матеріалами до кожного практичного заняття, так і в цілому за модуль у двох режимах: навчання та контроль. Комп'ютерне тестування за умови наявності якісних тестових за-

\section{Список літератури}

1. Горшунова Н. К. Інноваційні технології в підготовці лікаря в системі безперервної професійної освіти / Н. К. Горшунова // Фундаментальні дослідження. 2009. - № 2. - С. 87-88.

2. Закон України про вищу освіту : за станом на 1 лип. 2014 р. № 1556-VII / Відомості Верховної Ради України. 2014. - T. 2004, № 37-38.

3. Компетентнісний підхід в освіті: теоретичні засади і практика реалізації : матеріали методол. семінару (Київ, 3 квіт. 2014 р.) / Нац. акад. пед. наук України; редкол.: вдань дозволяє оперативно і об’єктивно оцінити і порівняти рівень підготовки студентів.

Висновки: 1. В сучасних умовах навчання студентів використання мультимедійних технологій сприяє вдосконаленню та покращенню інформаційного забезпечення навчального процесу на кафедрі медичної біології.

2. Діяльність викладачів повинна бути направленою на якісне інформаційне забезпечення студентів навчальними матеріалами, тестовими завданнями, ефективне управління освітнім процесом.

3. Використання мультимедійних технологій i принципу співпраці викладача та студентів сприяє вдосконаленню навчально-виховного процесу.

4. Комп’ютерне тестування як інноваційний метод оцінювання знань студентів дасть можливість одержати адекватну інформацію про якість навчання студентів при умові наявності чіткого алгоритму дій і єдиного підходу до проведення контролю та створення адекватної бази тестів.

В. Г. Кремень, В. І. Луговий, О. І. Ляшенко та ін. - К. : Ін-т обдарованої дитини НАПН України, 2014. - 370 с.

4. Опар Н. В. Особливості нормативно-правового забезпечення якості вищої освіти в Україні в умовах євроінтеграції / Н. В. Опар. - Режим доступу : httl:// el-zbirn-du.at.ua/2015_1/22.pdf.

5. Фіцула М. М. Педагогіка вищої школи / М. М. Фіцула. - К. : Академвидав, 2006. - С. 148-159.

6. Челышкова Н. Б. Теория и практика конструирования педагогических тестов / Н. Б. Челышкова. - М. : Информационно-издательский дом “Филинг”, 2003. - 236 с. 